5. West Nile virus activity-United States, 2006. MMWR Morb Mortal Wkly Rep 2007;56:556-559.

6. Cashman NR, Trojan DA. Correlation of electrophysiology with pathology, pathogenesis, and anticholinesterase therapy in post-polio syndrome. Ann NY Acad Sci 1995;753:138-150.

7. Dalakas MC. The post-polio syndrome as an evolved clinical entity. Definition and clinical description. Ann NY Acad Sci 1995; 753:68-80.

\section{VISUAL FUNCTION AT BASELINE AND 1 MONTH IN ACUTE OPTIC NEURITIS: PREDICTORS OF VISUAL OUTCOME}

To the Editor: In the article by Kupersmith et al., there was a sentence that is confusing and may be misleading: "At 6 months, visual acuity was 20/50 or worse in $79 \%$ of patients with $20 / 200$ or worse acuity at baseline."1 Actually, this percentage $(79 \%)$, according to their previous article, corresponds to the ratio of the number of patients with poor visual recovery at 6 months whose baseline visual acuity was $20 / 200$ or worse $(n=22)$ to the total number of patients with poor visual recovery at 6 months $(\mathrm{n}=29)$. $^{2}$

The true percentage of patients with visual acuity 20/50 or worse at 6 months among patients with baseline visual acuity $20 / 200$ or worse is $14 \%$ (22/156).

Olivier F. Gout, Paris, France

Disclosure: The author reports no conflicts of interest.
Reply from the Authors: We thank Dr. Gout for his comments on our article. He is correct. The senior author misinterpreted the data in table $5^{2}$ as row percentages but they were column percentages.

The correct statement would be as follows: "Among patients with 6-month visual acuity $\leq 20 / 50$, at baseline $79 \%$ had $\leq 20 / 200,17 \%$ had $20 / 50-20 / 190$, and $7 \%$ had $\geq 20 / 40$ visual acuity. Six-month acuity $\leq 20 / 50$ occurred in $15 \%$ with $\leq 20 / 200$, 4\% with $20 / 50-20 / 190$, and $1 \%$ with $\geq 20 / 40$ at baseline."

Thus, as previously stated, recovery is not as good with poor baseline visual acuity but even with $\leq 20 / 200$ at baseline, recovery to $\geq 20 / 40$ occurs in $85 \%$.

Mark J. Kupersmith, Robin Gal, Roy Beck, Neil Miller, New York, NY

Disclosure: The authors report no conflicts of interest.

Editor's Note: To ensure that the literature record is corrected, an erratum appears below.

Copyright (C) 2008 by AAN Enterprises, Inc.

1. Kupersmith MJ, Gal RL, Beck RW, Xing D, Miller N, the Optic Neuritis Study Group. Visual function at baseline and 1 month in acute optic neuritis: predictors of visual outcome. Neurology 2007;69:508-514.

2. Beck R, Cleary P, Jye-yu, Backlund M, Optic Neuritis Study Group. The course of visual recovery after optic neuritis: experience of the Optic Neuritis Treatment Trial. Ophthalmology 1994;101:1771-1778.

\title{
CORRECTION
}

Visual function at baseline and 1 month in acute optic neuritis: Predictors of visual outcome

In the article "Visual function at baseline and 1 month in acute optic neuritis: Predictors of visual outcome" by M.J. Kupersmith et al. and The Optic Neuritis Study Group (Neurology ${ }^{\mathbb{B}}$ 2007;69:508-514), the data in table 5 were misinterpreted as row percentages but they were actually column percentages. The correct statement in the article should read as follows: "Among patients with 6-month visual acuity $\leq 20 / 50$, at baseline $79 \%$ had $\leq 20 / 200$, $17 \%$ had $20 / 50-20 / 190$, and $7 \%$ had $\geq 20 / 40$ visual acuity. Six-month acuity $\leq 20 / 50$ occurred in $15 \%$ with $\leq 20$ / $200,4 \%$ with $20 / 50-20 / 190$, and $1 \%$ with $\geq 20 / 40$ at baseline." 


\section{Neurology}

\section{Visual function at baseline and 1 month in acute optic neuritis: Predictors of visual outcome}

Neurology 2008;70;738-738-a

DOI 10.1212/01.wnl.0000311043.84658.6f

This information is current as of February 25, 2008

\section{Updated Information \&}

Services

Permissions \& Licensing

Reprints including high resolution figures, can be found at: http://n.neurology.org/content/70/9/738.2.full

Information about reproducing this article in parts (figures,tables) or in its entirety can be found online at:

http://www.neurology.org/about/about_the_journal\#permissions

Information about ordering reprints can be found online:

http://n.neurology.org/subscribers/advertise

Neurology ${ }^{\circledR}$ is the official journal of the American Academy of Neurology. Published continuously since 1951, it is now a weekly with 48 issues per year. Copyright . All rights reserved. Print ISSN: 0028-3878. Online ISSN: 1526-632X.

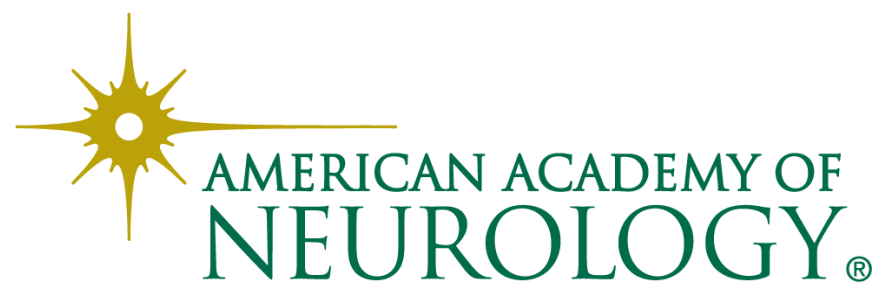

